\title{
STUDY ON THE CAPABILITY OF BIO-BUTANOL SYNTHESIS FROM SUGARCANE BAGASSE
}

\author{
Huynh Quyen ${ }^{(1)}$, Phan Dinh Tuan ${ }^{(2)}$ \\ ${ }^{(1)}$ Petroleum Refinery and Petrochemicals Technology Research Center \\ ${ }^{(2)}$ Laboratory for Bioenergy and Biomass Research \\ Hochiminh City University of Technology, VNU-HCM \\ (Manuscript Received on May 13 $3^{\text {th }}, 2011$, Manuscript Revised November 01 ${ }^{\text {st }}$, 2011)
}

\begin{abstract}
The main concern in converting sugarcane bagasse to bio-butanol fuel is the conversion of the polysaccharides by enzymatic breakdown into monosaccharides. This study focused on the use of steam explosion as a pretreatment method. Steam explosion treatment of biomass had been previously used to increase cellulose accessibility ${ }^{[1,3,5,6,8,9]}$. Following steam explosion pretreatment, sugarcane bagasse was subjected to enzymatic hydrolysis employing the Acremonium Cellulase as the reactant. The sugars released by enzymatic hydrolysis were further fermented by Clostridium Beijerinckii. Raw sugarcane bagasse was found to have the polysaccharides content of $56.24 \%$. The fiber loss during the steam explosion treatment was high, up to $67.11 \%$. Steam explosion treatment on sugarcane bagasse increased the enzymatic hydrolysis capability of cellulose. After steam explosion treatment at temperature of $224^{\circ} \mathrm{C}$ for 2 minutes, the cellulose hydrolysis conversion efficiency could reach $98.04 \%$ by applying Acremonium Cellulase for 72 hours.

It has been stated that steam explosion was suitable to improve cellulose content and consequently improve fermentable glucose yield from enzymatic hydrolysis while drastically reducing hemicellulose content of the fibers. Butanol has been successfully produced from the sugarcane bagasse hydrolysate in acetone-butanol-ethanol (ABE) process applying C. Beijerinckii.
\end{abstract}

Keywords: Butanol, sugarcane bagasse, steam explosion

\section{INTRODUCTION}

In the 20th century, the world economy has been dominated by technologies that depend on fossil energy, such as petroleum, coal, or natural gas to produce fuels, chemicals, materials and power. However, fossil energy sources are coming gradually exhausted. Worldwide crude oil production was forecasted to decline from 25 billion barrels in 2005 to about 5 billion barrels in $2050^{[6]}$. A search for other energy sources is advisable.

Meanwhile, governments and people around the world are concerned about global warming. Global warming is the theory that the buildup of greenhouse gases (GHG) in the earth's atmosphere, like carbon dioxide, traps more of the sun's radiation, causing the earth to become warmer. The largest sources of carbon dioxide 
emissions are the burning of fossil fuels. In 2006, the burning of coal to generate electricity contributed to approximately $38.9 \%$ of the carbon dioxide emissions, while fossil fuels used in transportation, like gasoline and diesel fuel contributed approximately $31.0 \%{ }^{[7]}$. Thus, people could mitigate its carbon dioxide emissions by substituting biofuels for fossil fuels used in the transportation sector.

It is useful with an overview of main reasons for introduction of biofuels:

- Biofuels are oxygenates: Oxygenated fuel tends to burn cleaner, reducing tail pipe emissions from hydrocarbons, carbon monoxide, particulate emissions, and sulfur dioxide; decreasing vehicle contributions to local air pollution. Most biofuels have a cleaner burning than common fossil petrol and diesel.

- Higher reliability of energy supply: With more sources of fuel, the prices become more stable and shortage is less probable.

- Industrial and commercial development of a new industry, with increased employment and possibilities of development of intellectual capital: The introduction of biofuels will encourage the employment in the whole chain, from cultivation, harvesting, to processing and distribution.

Biofuels obviously mitigate global warming by recycling carbon dioxide from the atmosphere. Plants absorb carbon dioxide and release oxygen back into the atmosphere. The carbon becomes stored in a plant's cellulose, hemicellulose, starches, sugars, and oils, anh then human beings will process the plants into biofuels used in transportation and industry. As people drive their cars and trucks, the biofuel is combusted and converted back to carbon dioxide.

Researchers have extensively studied ethanol and biodiesel. However, one potential overlooked alternative is butanol. Butanol might be used as a fuel in an internal combustion engine. Because of its longer hydrocarbon chain, causing it to be fairly nonpolar, it is more similar to gasoline than it is to ethanol. Butanol has been demonstrated to work in vehicles designed for use with gasoline without modification.

Basically, the biofuels can be produced from lignocellulosic biomasses. Lignocellulosic biomass composes mainly cellulose, hemicellulose, and lignin. The cellulose fibers are usually embedded in an amorphous matrix of hemicellulose and lignin. The presence of lignin in the biomass lowers the biodegradability both of the cellulose and hemicellulose. The ideal pretreatment would remove only the lignin portion without loss of hemicellulose or cellulose. An effective pretreatment must improve the availability of sugars, prevent degradation of carbohydrate, reduce unfavorable byproducts, and be low cost. Numerous pretreatment methods including physical, physicochemical, chemical, and biological methods have been developed for separation of lignocellulosic to cellulose, hemicellulose, and lignin.

As lignocellulosic biomass, the agricultural residues and wastes used for the production of

\section{Trang 88}


biofuels (including $\mathrm{ABE}$ ) include rice straw, wheat straw, sugarcane bagasse, wood (hardwood), byproducts left over from the corn milling process (corn fiber), annual and perennial crops, and waste paper. These substrates are composed primarily of polysaccharides that contain six and five carbon sugars. Prior to use of these substrates, these feedstocks must be hydrolyzed using a combination of alkali/acid pretreatment or enzymes $^{[4,6]}$. Butanol producing cultures (Clostridium Acetobutylicum and/or Clostridium Beijerinckii) have an added advantage over natural ethanol producing strains that they can utilize both hexose and pentose sugars released from agricultural residues.

In this paper we research on capability of the butanol synthesis from sugarcane bagasse using steam explosion as a pretreatment method, with employing Clostridium Beijerinckii for butanol fermentation.

\section{METERIAL AND METHODS}

Butanol Synthesis Process was described as Figure 1. Sugarcane bagasse used in this research was gathered from The Sugar Mill Bien Hoa in Tay Ninh town, and stored in conventional conditions. Raw samples were obtained from the sugar mill at the tail end of the sugaring season in February. Sugarcane bagasse contains $50-55 \%$ cellulose, 20-25\% hemicellulose, and relatively low lignin (10-
$15 \%)$. The moisture content of the bagasse was about $13-15 \%$. This bagasse was used for all experiments. Enzyme Acremonium Cellulase used in this research was supplied by the JICAJST Project to Hochiminh City University of Technology. Clostridium Beijerinckii was supplied by the Institute of Tropical Biology, Vietnam Academy of Science and Technology. Spores of the culture were stored in distilled water at $4^{\circ} \mathrm{C}$ in $1.5 \mathrm{~mL}$ eppendorfs.

Total dry matter was determined by weight method, based on raw samples or on steamexploded ones. Samples dried by this procedure were used for subsequent fatty matter determination by Soxhlet Extractor with Ethanol/Benzene reagents mixture (ratio of $1 / 2$ ). A neutral detergent solution is used to dissolve the easily digested pectin and plant cell contents (proteins, sugars and lipids), leaving a fibrous residue (NDF) that is primarily cell wall components of plants (cellulose, hemicellulose and lignin). Besides, an acidified quaternary detergent solution (ADS) is used to dissolve the cell solubles, hemicellulose and soluble minerals, leaving the residue of cellulose, lignin, and heat damaged protein and a portion of cell wall protein and minerals (ash). In the next step, Acid Detergent Lignin Procedure (ADL) is applied to determine gravimetrically the residue remaining upon ignition after $72 \% \quad \mathrm{H}_{2} \mathrm{SO}_{4}$ treatment. This procedure helps to determine the percentage of cellulose, or lignin or ash. 


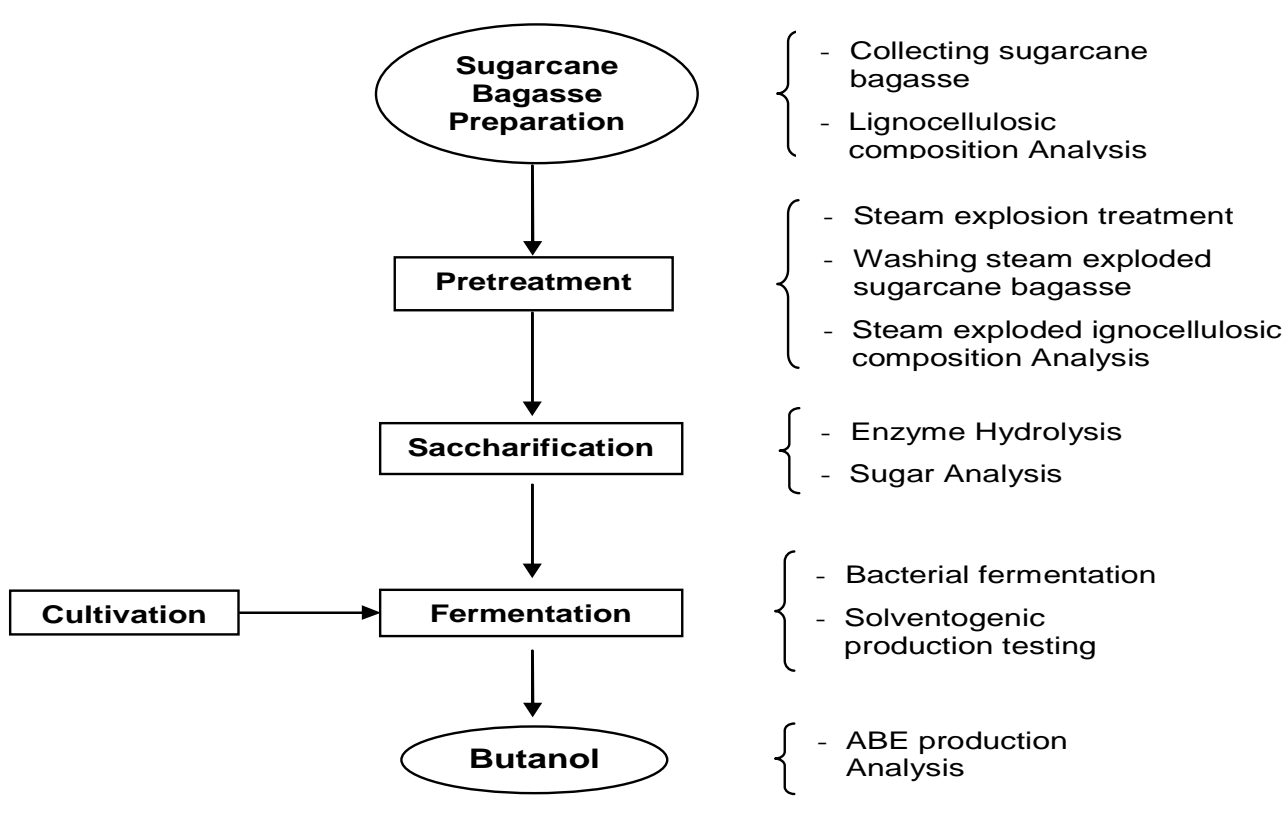

Figure 1: Butanol Synthesis Process.

The steam explosion of the sugarcane bagasse samples was carried out in a $5 \mathrm{~L}$ batch reactor. The process was done at select temperatures In the range of 223-230 ${ }^{\circ} \mathrm{c}$ and with retention times of 2,3,4,5 min, respectively times of 2, 3, 4 and 5 minutes. The exploded product was released in a sludge form and was strained using a cotton mesh cloth for fibers. The fibers were washed, bagged and weighed and further moisture determination.

In order to prepare hydrolysis broth, about $21 \mathrm{~g}$ pretreated sugarcane bagasse sample was suspended in $100 \mathrm{~mL}$ of Acetate buffer solution $(\mathrm{pH}$ of 5.7) in $250 \mathrm{~mL}$ flask, followed by autoclaving at $121^{\circ} \mathrm{C}$ for 15 minutes and then cooling to $36^{\circ} \mathrm{C}$. After this, $0.15 \mathrm{~g}$ of solid enzyme Acremonium Cellulase was added and mixed well. Finally, the mixture was incubated at $50^{\circ} \mathrm{C}$ for 72 hours with agitation at 80rpm.During saccharification, $1.5 \mathrm{~mL}$ samples were taken after each 24 hours for sugar measurement. The samples were centrifuged for 15 minutes to separate sediments, and the clear liquid was stored at $0^{\circ} \mathrm{C}$ before sugar analysis. After incubation, the mixture was filtered to remove sediments, and $\mathrm{pH}$ was adjusted to 6.5. The solution was then autoclaved at $121^{\circ} \mathrm{C}$ for 15 minutes before being stored at $4^{\circ} \mathrm{C}$ for fermentation studies to be conducted later.

\section{Trang 90}




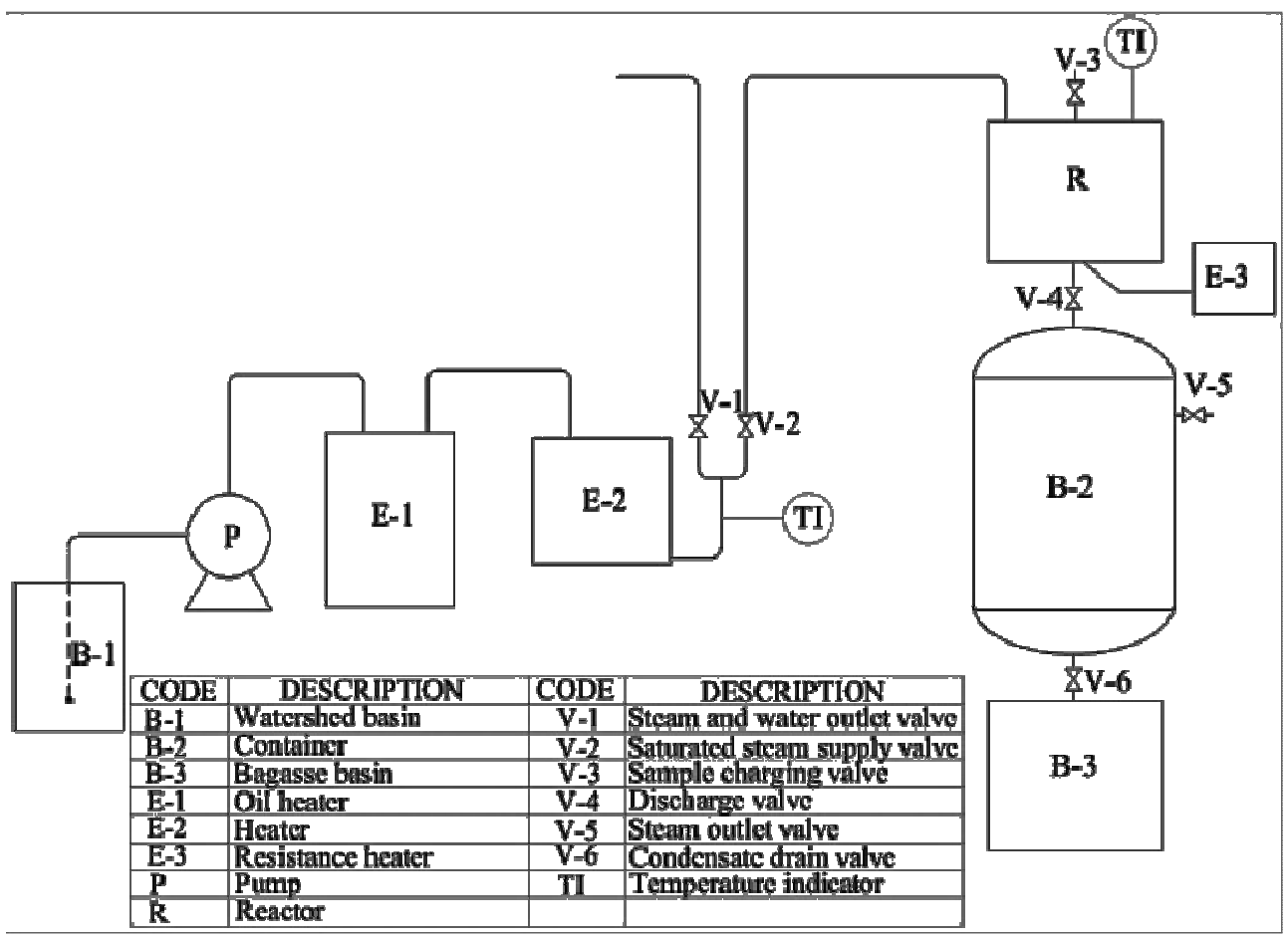

Figure 2. Steam explosion Process

Fermentation studies were conducted in $12 \mathrm{~mL}$ screw capped tubes containing $10 \mathrm{~mL}$ medium. Anaerobic conditions inside the medium were indicated by Resazurin - a blue dye used mainly as an oxidation-reduction indicator in the resazurin test for bacteria. Prior to placing the tubes in an incubator, caps were loosened to facilitate exchange of gases between jars (anaerobic gases) and the medium inside tubes. Then the tubes were inoculated with $0.5-1 \mathrm{~mL}$ of actively growing $72 \mathrm{~h}$ old culture developed above.

Fermentation was conducted at $36^{\circ} \mathrm{C}$ until the culture ceased the $\mathrm{ABE}$ production (about 7 days). Then, $1.5 \mathrm{~mL}$ samples were taken for sugar and $\mathrm{ABE}$ measurement. To do that, the samples were centrifuged for 15 minutes to separate sediments, and the clear liquid was stored at $0^{\circ} \mathrm{C}$ before $\mathrm{ABE}$ and sugar analysis.

For ABE and sugar analysis, $100 \mathrm{~mL}$ sterilized sugarcane bagasse hydrolysate $(\mathrm{SBH})$ solution was transferred to $250 \mathrm{~mL}$ presterilized flask. At this stage, $\mathrm{pH}$ of the solution was adjusted to 6.5 with $10 \mathrm{M} \mathrm{NaOH}$ solution. T6 medium containing vitamin, buffer and mineral $[8,9]$ was added to the SBH solution. The flask was then placed in an incubator for an anaerobiosis for 72 hours at $36^{\circ} \mathrm{C}$. After 72 hours, the flask was inoculated with $8-10 \%$ 
(v/v) of actively growing 72 hours old culture developed as above mentioned.

Fermentation products (ABE, acetic acid, and butyric acid) as well as sugars were analyzed by a SHIMADZU High Performance Liquid Chromatography (HPLC) using a packed column Rezex RNM - Carbonhydrate with water as mobile phase, flow rate of $0.6 \mathrm{~mL} / \mathrm{min}$, at $50^{\circ} \mathrm{C}$. Before injection into the HPLC, the samples were centrifuged for 15 minutes followed by diluting tenfold with distilled water. ABE productivity was calculated as total ABE (present in the reactor plus condensate) produced in $1 / \mathrm{gL}$ divided by the fermentation time and is expressed as 1/gL.h. ABE yield was calculated as total ABE produced divided by the total sugar utilized.

\section{RESULTS AND DISCUSSIONS}

The composition of sugarcane bagasse was summarized in Table 1.

Fiber losses occur during steam explosion because of the deposition of fibers on the walls of the container as well as in the connecting piping between the reactor vessel and the container. Losses also occurred through the escape of volatiles with the steam and through the degradation of sugars into furfural and 5hydroxymethyl furfural, both of which are volatile compounds. To minimize these losses, blank runs with water were carried out after each batch. The liquid obtained from the blank runs was strained to recover the fiber. Table 2 summarizes the solids recovery such as total solids, fibers, and cellulose recovery for each steam-exploded batch.

The batch S4 resulted pretty well (Table 2). Its solid recovery values was higher than those of the others. Fiber recovery values obtained in this study were in the range of $27.47 \%$ to $32.89 \%$. The average fiber recovery of the 7 samples was $30.05 \%$.

As with the raw material, the steam exploded substrates were analyzed for fatty matter, organic components, cellulose, hemicellulose, lignin and ash. Table 3 shows the composition of steam-exploded sugarcane bagasse.

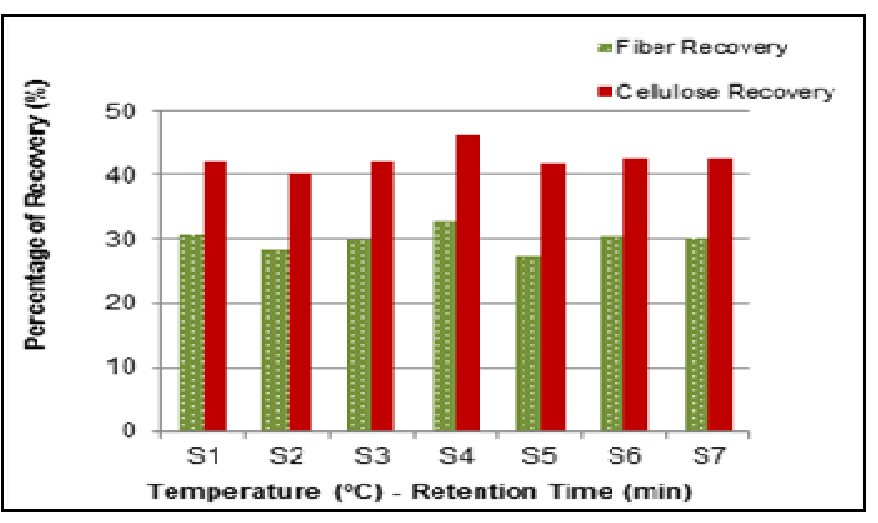

Figure 3. Solid recovery in steam explosion treatment

\section{Trang 92}


Table 1. Composition of raw sugarcane bagasse.

\begin{tabular}{|l|c|}
\hline \multicolumn{1}{|c|}{ Composition } & Dried material (\%,w/w) \\
\hline Fatty matter & 2.57 \\
\hline Organic components & 8.98 \\
\hline Cellulose & 50.62 \\
\hline Hemicellulose & 24.83 \\
\hline Lignin & 10.03 \\
\hline Ash & 2.96 \\
\hline$\quad$ Total & $\mathbf{9 9 . 9 9}$ \\
\hline
\end{tabular}

Table 2.Solid Recovery in steam explosion treatment

\begin{tabular}{|c|c|c|c|c|c|}
\hline \multirow[b]{2}{*}{ Batch } & \multicolumn{2}{|c|}{ Severities } & \multirow{2}{*}{$\begin{array}{c}\text { Total solid } \\
\text { Recovery } \\
(\%)\end{array}$} & \multirow{2}{*}{$\begin{array}{c}\text { Fiber } \\
\text { Recovery } \\
(\%)\end{array}$} & \multirow{2}{*}{$\begin{array}{c}\text { Cellulose } \\
\text { Recovery } \\
(\%)\end{array}$} \\
\hline & $\begin{array}{c}\text { Temperature } \\
\left({ }^{\circ} \mathrm{C}\right)\end{array}$ & $\begin{array}{l}\text { Retention } \\
\text { time(min) }\end{array}$ & & & \\
\hline S1. & 230 & 2 & 62.99 & 30.81 & 42.06 \\
\hline S2. & 229 & 2 & 60.33 & 28.35 & 40.18 \\
\hline S3. & 229 & 2 & 59.27 & 29.99 & 42.15 \\
\hline$S 4$. & 224 & 2 & 62.65 & 32.89 & 46.35 \\
\hline S5. & 224 & 3 & 59.85 & 27.47 & 41.81 \\
\hline S6. & 223 & 4 & 61.45 & 30.60 & 42.69 \\
\hline S7. & 223 & 5 & 60.11 & 30.25 & 42.51 \\
\hline
\end{tabular}

The study has been focused on the period of 72 hours to observe enzymatic activity over the course of the hydrolysis and the effect of the pretreatment method. The effect of steam explosion on the conversion of cellulose into glucose monomers was also investigated. The question here was if steam explosion pretreatment had a positive effect on the accessibility of the cellulase enzymes to the pretreated cellulose fibers.

The saccharification batch was conducted with the help of Acremonium Cellulase (4\% ,w/v) and strong agitation, at $50^{\circ} \mathrm{C}$. The glucose production performance of the enzyme was shown in figure 3. 


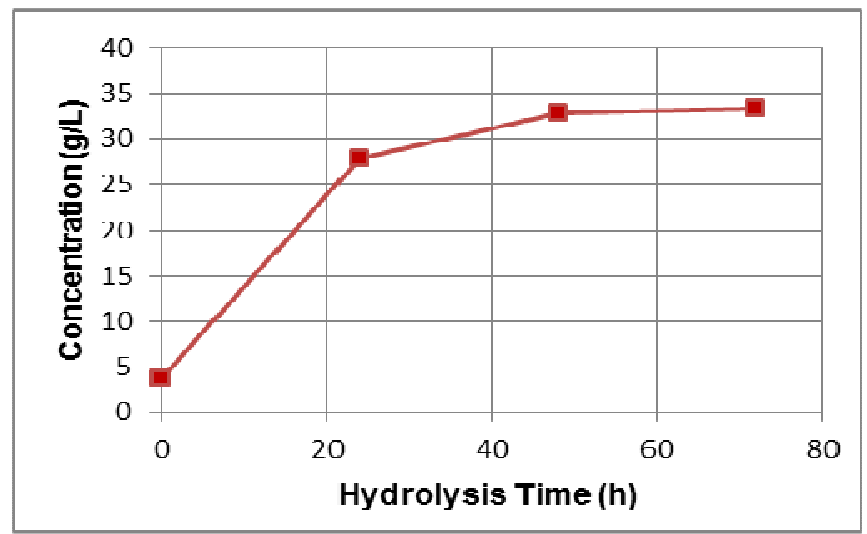

Figure 4. Saccharification process behavior in batch mode

It is clear from the figure, that the glucose appeared at the beginning of the process, This observation supported for the idea that the fibers might be partially hydrolyzed during steam pretreatment ${ }^{[4]}$. Consequently, the maximum glucose concentration obtained in enzymatic hydrolysis was $33.42 \mathrm{gL}^{-1}$, which would be used for further bacterial fermentation.

After 72 hours of fermentation, samples were taken for solvents test. In the study, only acetone has been tested. Sodium nitroprusiate and ammonium hydroxide were used in the test. The color of fermented medium translated into nearly purple. It meant that the bacteria has successfully produced acetone in the solventogenic phase. In order to ensure the theoretical basis for butanol production, samples after 72 hour fermentation have been taken for ABE measurements.

\section{CONCLUSIONS}

Sugarcane bagasse is a potential feedstock for the production of biofuel in general and biobutanol in particular. Steam explosion was found to be a suitable pretreatment method, in terms of shortening pretreatment time and making it accessable for enzymatic hydrolysis. Moreover, the study has stated that Clostridium Beijerinckii is a potential bacterium which can ferment sugarcane bagasse hydrolysate into butanol.

In order to make the biobutanol production from sugarcane bagasse promising, it is necessary to clarify further technological factors which might influence the process, especially the fermentation and the separation of reaction products.

\section{Trang 94}




\title{
BƯớC ĐẦU NGHIÊN CƯU KHẢ NĂNG TỔNG HỢP BIO-BUTANOL TÙ BÃ MÍA
}

\author{
Huỳnh Quyền, Phan Đình Tuấn \\ (1) Trung tâm Nghiên cứu Công nghệ Lọc Hóa Dầu \\ (2) Phòng thí nghiệm Năng lượng Sinh học và Biomass \\ Trường Đại học Bách khoa, ĐHQG-HCM
}

TÓM TÁT: Yêu cầu chủ yếu của quá trình chuyển hóa bã mía thành bio-butanol nhiên liệu chính là việc chuyển hóa các polysaccharides thành monosaccharides bằng enzyme. Bài báo này tập trung nghiên cứu sử dụng phuoong pháp nổ hơ để xử lý sơ bộ nguyên liệu. Phương pháp xử lý nguyên liệu bằng nổ hơi này đã được công bố truơớc đây nhằm làm tăng khả năng tác dụng cellulose của các chất phản ứng ${ }^{[1,3,5,6,8,9]}$. Sau khi nổ hoi, bã mía được thủy phân bằng enzyme Acremonium Cellulase. Đường thu được được tiếp tục lên men bằng Clostridium Beijerinckii.

Bã mía nguyên liệu có hàm luợng polysaccharides 56.24\%. Mất mát sợi trong quá trình nổ hơi tỏ ra khá cao, đến 67.11\%. Quá trình xủ lý bã mía bằng nổ hoi làm tăng khả năng thủy phân cellulose trong bã mía bằng enzyme. Sau khi nổ hơ ở nhiệt độ $224^{\circ} \mathrm{C}$ trong 2 phút, hiệu suất thủy phân có thể đạt 98.04\% khi sủ dung Acremonium Cellulase trong 72 giò.

Tù các nghiên cứu này, có thể chỉ ra rằng nổ hơi là phuoong pháp xủ lý phù hợp để tăng hàm luợng cellulose và do đó làm tăng hàm luợng glucose có thể lên men ethanol sau khi thủy phân bằng enzyme và làm giảm đáng kể hàm luợng hemicellulose trong sợi bã mía. Nhóm nghiên cứu đã sản xuất thành công butanol nhờ quá trình lên men acetone-butanol-ethanol (ABE) khi sủ dụng chủng nấm men C. Beijerinckii.

Tù khóa: Butanol, sugarcane bagasse, steam explosion

\section{REFERENCES}

[1]. Atalla, R. H. 1988. Structural Transformations in Celluloses. Proceedings of the International Workshop on Steam Explosion Techniques: Fundamentals and Industrial Applications 97-119.

[2]. Chen C-K, Blaschek HP. 1999. Acetate enhances solvent production and prevents degeneration in Clostridium beijerinckii BA101. Appl Microbiol Biotechnol 52:170173.
[3]. Excoffier, G., A. Peguy, M. Rinaudo, M. R. Vignon. 1988. Evolution of Lignocellulosic Components During Steam Explosion. Potential Applications. In B. Focher, A. Marzetti and V. Crescenzi (Eds.) Proceedings of The International Workshop on Steam Explosion Techniques: Fundamentals and Industrial Applications 83-95.

[4]. Excoffier, G., Toussaint, B., Vignon, M.R., 1991. Saccharification of steam-exploded 
poplar wood. Biotechnol. Bioeng. 38, 13081317.

[5]. Focher, B., A. Marzetti, P. L. Beltrame, P. Carniti, A. Visciglio. 1988. Steam Explosion of Wheat Straw. Product Fractionation and Enzymatic Hydrolysis of the Cellulosic Component. In B. Focher, A. Marzetti and V. Crescenzi (Eds.) Proceedings of the International Workshop on Steam Explosion Techniques: Fundamentals and Industrial Applications 331-340.

[6]. Ghose, T.K., Bisaria, V.S., 1979. Studies on mechanism of enzymatic hydrolysis of cellulosic substances. Biotechnol. Bioeng. 21, 131-146.

[7]. Kaar, W. E., C. V. Gutierrez, C. M. Kinoshita. 1998. Steam Explosion of Sugarcane Bagasse as a Pretreatment for
Conversion to Ethanol. Biomass and Bioenergy 14(3): 277-287.

[8]. Tanahashi, M., K. Tamabuchi, T. Goto, T. Aoki, M. Karina, T. Higuchi. 1988. Characterization of Steam-Exploded Wood II Chemical Changes of Wood Components by Steam Explosion. Wood Research 75:112.

[9]. Tanahashi, M., S. Takada, T. Aoki, T. Goto, T. Higuchi, S. Hanai. 1983. Characterization of Explosion Wood 1. Structure and Physical Properties. Wood Research 69:36-51.

\section{Trang 96}

